\title{
A hivatalos dokumentum útja a hatóságtól a fordítóig - előtanulmány angol nyelvü pakisztáni hivatalos iratok magyar fordításáról
}

\author{
Benedek Enikö \\ E-mail: eniko.work@gmail.com
}

\begin{abstract}
Kivonat: A kulturális háttérismeret elengedhetetlen a távoli kultúrkörből származó szövegek fordításához, különös tekintettel a hivatalos szervek által kiállított és magyarországi hivatalokhoz benyújtani kívánt iratokra. A szerző korábbi tanulmánya folytatásaként az esettanulmányban egy Pakisztáni Iszlám Köztársaság területén kiállított, angol nyelvű hivatalos személyi dokumentum különböző magyar fordításait vizsgálja meg, amelyeket az Országos Fordító- és Fordításhitelesítő Iroda, egy iszlámábádi fordítóiroda, három szakfordító és négy fordítószakos hallgató készített el. A tanulmány megvizsgálja, hogy a dokumentum mely részei jelentették a fordítók számára a legnagyobb kihívást és hogyan hidalható át e kulturális szakadék.
\end{abstract}

Kulcsszavak: interkulturális kommunikáció, reália, Pakisztán, kulturális átváltás, kulturális kompetencia, hivatalos dokumentum

\section{Bevezetés}

A Pakisztánban kiállított hivatalos dokumentumok föként urdu vagy angol nyelven íródtak, számos esetben mindkét nyelvet tartalmazzák, mivel a volt brit gyarmat területén az angol nyelv használata napjainkban is elterjedt, az urdu mellett az ország hivatalos másik nyelve. A pakisztáni angol a kulturális hatások következtében azonban főként arab nyelvi eredetű iszlám vallási terminusokkal tüzdelt, amelyek magyarra fordítása próbára teheti a fordító kutatói készségeit. A magyartól teljesen eltérő közigazgatási rendszer, ezen belül az intézmények felépítése és jellemzői, az ügyintézés folyamata, valamint a lakosság dokumentációja sokban különbözik a magyar fordító által ismerttől. A fordító feladata, hogy olyan fordítást hozzon létre, amely a célnyelven be tudja tölteni funkcióját, szkoposza tehát meghatározza a fordítási stratégiát (Vermeer 1978: 100). Az elemzés tárgyát képezi a forrásnyelvi szöveg, amelynek Pakisztánban kiadott

Hivatkozás: Benedek E. 2019. A hivatalos dokumentum útja a hatóságtól a fordítóig - előtanulmány angol nyelvü pakisztáni hivatalos iratok magyar fordításáról. Forditástudomány 21. évf. 2. szám. 17-31. DOI: https://doi.org/10.35924/fordtud.21.2.2 
magyar fordítását, az Országos Fordító- és Fordításhitelesítő által kiadott fordítását, valamint három szakfordító és négy fordító- és tolmácsképzésben részt vevő hallgató által készített fordítását vetjük egybe az elméleti háttérben megfogalmazott szempontok alapján.

Hofstede (1994) 1960-as és 1970-es években végzett nemzetközi kutatásai alapján megállapította, hogy a különböző kultúrák problémakörei általában azonosak, de eltérő megoldásokban gondolkodnak a társadalmi egyenlőtlenségek kezelésében, az egyén és a csoport egymáshoz viszonyulásával kapcsolatban, a feminin vagy maszkulin értékrend előtérbe helyezésében, és az élet kiszámíthatatlanságára felkészülésben. A kutatás kiindulópontja, hogy Magyarország és Pakisztán e kérdésekben eltérő módon gondolkodik, ezért kultúráink különböznek egymásétól. E különbségek a nyelvben is megmutatkoznak. Banczerowski (2008: 193) hangsúlyozza, hogy gondolkodásunk tükröződik a nyelvhasználatban, egyfajta másodlagos képet alakít ki a bennünket körülvevő világról. Feltételezhető, hogy ellenkező irányból megközelítve a kérdést, a nyelv alapján következtethetünk a másik kultúra világképére és gondolkodásmódjára.

Heltai (2012: 3) szerint a különböző nyelveket beszélő emberek gondolkodásmódját, világszemléletét az általuk örökségül kapott nyelv erősen befolyásolja. Ehhez azonban nem szabad figyelmen kívül hagyni a fordítást megnehezítő konnotatív jelentéstöbbletet, amelyet a kultúra minél mélyebb ismeretével tárhatunk fel. A kultúrától függő nyelvi elemeket reáliának nevezzük. Valamely kultúrára sajátosan jellemző jeltárgy vagy fogalom és annak elnevezéseként definiáljuk, amelynek a másik kultúrában nincs megfelelője, vagy más a konnotációja (Klaudy 2013: 85). A terminust a nyelvközösségre sajátosan jellemző jeltárgyakra és azok megnevezésére is használhatjuk (Tellinger 2005: 123). A jeltárgy és megnevezése elkülönítésére a jeltárgyra a reália, megnevezésére pedig a reálialexéma terminust célszerü használni (Mujzer-Varga 2007, 2009).

Heltai (2012) felhívja a figyelmet arra is, hogy nem minden nyelvi sajátosságot lehet visszavezetni valamilyen közvetlenül nem érzékelhető kulturális különbségre, a csak az adott nyelvre jellemző elemek nyelvspecifikusak, az adott kultúrára visszavezethetők pedig kultúraspecifikusak. E kategóriák egymással átfedésben vannak, így a nyelvspecifikus elemek lehetnek kultúraspecifikusak és nem kultúraspecifikusak, ugyanígy a kultúraspecifikus elemek visszavezethetők nyelvi sajátosságokra és nem nyelvi sajátosságokra. Az előtanulmány egy további kérdésre is választ keres: a dokumentum használhatósága szempontjából kritikus elemek fordításait vizsgálja, amelyekben a kultúraspecifikusság szó- és mondatszerkesztési szinten is megmutatkozik. Az előtanulmány további célja fordítói segédletet nyújtani a terminusok magyar megfelelőinek megtalálásához.

\section{Elméleti háttér}

Az esettanulmányban elemzett kísérlet eredményeinek vizsgálatához tisztázni szükséges a vizsgálat és értékelés szempontjait. A szkoposzelmélet megközelítés lényege, hogy a fordítási folyamatot a célnyelvi szöveg szkoposza határozza meg, amely a felhasználó igényeit tükrözi, tehát az ekvivalencia-megközelítésekkel 
(Catford 1965, Nida 1964, Nida és Taber 1969) ellentétben a befogadó helyzetét és kulturális hátterét veszi figyelembe. A fordításnak a szkoposzelmélet szerint a koherenciaszabálynak és a hüségszabálynak is meg kell felelnie, amelyek együttesen járulnak hozzá, hogy a fordítás funkcióját betölthesse. A koherenciaszabály kimondja, hogy a célnyelvi szövegnek elég koherensnek kell lennie ahhoz, hogy az olvasó a feltételezett háttértudása és a szituációja figyelembevételével készült fordítást megértse. A hüségszabály a forrásnyelvi szöveg és a fordítás közti intertextuális koherencia meglétét írja elő, amely szerint nem elég, ha a szkoposz- és a koherenciaszabály, azaz az intratextuális koherencia feltételei teljesülnek, a két szöveg közötti kapcsolatnak továbbra is fenn kell állnia.

A vizsgált forrásnyelvi szöveg hivatalos dokumentum, szkoposza a magyarországi ügyintézéshez szükséges információ közlése, amelynek hitelességét a dokumentum formátuma és a rajta szereplő bélyegzők igazolják. A fordítások szkoposza, hogy a hivatalos iratok felhasználhatóságára vonatkozó elvek betartásával készített fordítás a magyar hivatali terminológiába illeszkedjen, egyértelműen kifejezze a kulturálisan kötött elemek magyar jelentését és felhasználható legyen a hivatalos ügyintézés során.

A szkoposzelmélet mellett a vizsgálat tárgyát képező elemzés eredményeinek értékelésekor Klaudy kommunikatív ekvivalencia-elméletére (Klaudy 1999:99) támaszkodunk. A kommunikatív szempontból ekvivalens fordítást háromféle egyenértékűség jellemzi: referenciális, kontextuális és funkcionális ekvivalencia. A referenciális ekvivalencia a fordítás alapfeltétele, e szerint a fordítás a világ ugyanazon szeletét írja le, mint a forrásnyelvi szöveg. Ha nem ugyanazt a jelenséget írja le, a célnyelvi változat nem tekinthető fordításnak. Kontextuális egyezőséget vizsgálhatunk a mondat és a szöveg irányából. A szöveg felől vizsgálva azt jelenti, hogy a célnyelvi szöveg mondatai ugyanúgy kapcsolódnak egymáshoz, mint a nem fordítás eredményeként keletkezett múfajrokon szövegek esetében. A mondat felől megközelítve pedig azt jelenti, hogy a célnyelvi mondatok ugyanúgy kapcsolódnak egymáshoz, és vesznek részt a szöveg szerkesztésében, mint a forrásnyelvi mondatok a forrásszöveg esetében. A harmadik típusú egyenértékűség, a funkcionális ekvivalencia pedig arra épül, hogy a fordítás csak akkor tölthet be ugyanolyan szerepet a célnyelvi közönség körében, mint amilyet a forrásnyelvi szöveg a forrásnyelvi olvasók körében, ha illeszkedik a hasonló műfajú, célnyelvi szerzők által készített szövegek sorába (Klaudy 1999: 100).

Ennek alapján a kísérletben készített fordítási megoldásokat akkor tekinthetjük elfogadhatónak, ha célnyelvi funkciójukat betöltik, azaz megfelelnek a hivatalos dokumentumokkal szemben támasztott követelményeknek; koherensek, tehát a felhasználó értelmezni tudja őket saját háttértudása alapján; illetve fennáll a hüségszabály szerinti kapcsolat a két szöveg között.

Egy korábbi tanulmányban több dokumentumtípust vizsgálva három módot állapítottam meg a reálialexémák fordítására (Benedek 2019: 54):

(1) Lexikai átváltás: A forrásnyelvi elem a célnyelvben rendelkezik ekvivalens lexémával amelynek könnyen megfeleltethető.

(2) Átalakítás: A forrásnyelvi elem a célnyelvben nem rendelkezik ekvivalens lexémával, de más nyelvi eszközzel kifejezhető. 
(3) Kulturális átváltás: A forrásnyelvi elem a célnyelvi kultúra számára idegen, a fordítótól a célnyelvi elhelyezés többlet erőfeszítést, pragmatikai átváltást kíván. Három altípusba sorolhatjuk. Az első esetben a vizsgált kifejezés rendelkezik ugyan ekvivalens lexémával, de használati módja, referenciális jelentése vagy konnotációja miatt reálialexémának minősül (ez a lexikai-kulturális átváltás), vagy nem rendelkezik célnyelvi ekvivalenssel, mivel a fogalom nem létezik a célnyelvi kultúrában (tisztán kulturális átváltás vagy átemelés). Amennyiben kulturális háttérismeretek segítségével vagy a kontextus ismeretével a nyelv más eszközeivel hozható létre célnyelvi megfelelő, úgy egyszerre zajlik kulturális átváltás és átalakítás.

A fordító kizárólag nyelvismeretre támaszkodva hiányos, egyes esetekben hibás megoldásokat találhat, ezért az ilyen távoli kultúrkörben keletkezett dokumentumok fordításakor tárgykör helyett kultúrkör alapú szemléletre van szükség. A kulturális átváltáshoz szükséges mind a forrásnyelvi, mind a célnyelvi kultúra alapos ismerete, a kontextus figyelembevétele és a konnotációk ismerete egyaránt.

A fordítás nehézségét a kulturális háttérismeret hiánya adja, mivel e forrásnyelvi szöveg kifejezéseinek megtalálhatók a magyar ekvivalensei, a kísérletben részt vevő fordítók szerint mégis idegenszerü, némely esetben abszurd hatást kelt megfogalmazása.

\section{A kutatás}

A kutatás a célja rávilágítani a kulturális háttérismeretek fontosságára az ilyen távoli kultúrkörből származó szövegek megfelelő fordításához. Két kutatási kérdésre keresi a választ:

(1) A dokumentum mely részei jelentenek fordítási kihívást a résztvevők számára?

(2) A sikertelen megoldások milyen fordítói hiányosságra utalnak? Hogyan lehetne orvosolni a problémákat?

Az esettanulmány egy „Affidavit” című dokumentumot és különböző fordításait vizsgálja a dokumentumban szereplő, kihívást jelentő terminusok azonosításával, és célnyelvi változataik leírásával. A szerző készülő doktori disszertációja többféle dokumentumtípust vizsgál, amelyek közül az előtanulmány esetében a több kihívást jelentő terminust tartalmazó dokumentum fordításait elemzi. A fordításokat készítő magyar fordítóknak és fordító- és tolmácsszakos hallgatóknak a szövegről előzetesen nem volt ismeretük, a fordítást szövegszerkesztő programban készítették el, rendelkezésükre álltak az interneten található információk. A fordítás előtti instrukcióban mindössze a formai követelmények reprodukciója szerepelt, illetve, hogy a fordítást csak egyedül szabad elkészíteni, a megoldásokat nem szabad egymással megosztani, és hogy a forrásnyelvi dokumentumon lévő összes elemet kérjük lefordítani, az olvashatatlan részeket 
pedig kérjük jelölni. A fordítók naplót is készítettek a kísérlet közben a szöveggel kapcsolatos gondolataikról, leírták a nehézséget okozó kifejezést és a gondolatmenetet, amely alapján az adott megoldásra jutottak, illetve néhány esetben azt a weboldalt is, amelyen megtalálták a végül kiválasztott célnyelvi változatot. Választásukat és gondolatmenetüket legtöbb esetben fordítói kommentár formájában indokolták.

A készülő disszertáció korpuszában megtalálható születési anyakönyvi kivonat, erkölcsi bizonyítvány, eskü alatt tett nyilatkozat, családi állapot igazolásáról szóló okirat, házasságkötési engedély, halotti anyakönyvi kivonat, válási okirat és személyi igazolvány. A szerző e dokumentumok közül az előtanulmányhoz két forrásnyelvi okirat fordításában kérte az önkéntes közreműködők segítségét, melyek közül elsőként az „Affidavit” fordítását kérte. A kutatás tanulságai között említendő, hogy az első dokumentum fordítása a vártnál több időt vett igénybe, így csak egy fordítónak sikerült mindkét iratot lefordítania. Ezért ez az előtanulmány a több résztvevővel zajló jövőbeli vizsgálat kipróbálása.

\subsection{A vizsgálati korpusz}

A korpuszt az angol nyelvü dokumentum, hiteles magyar fordítása, egy minden bizonnyal gépi fordítással készült, Pakisztánban kiállított, pakisztáni fordítóiroda pecsétjével ellátott hivatalos magyar fordítása, továbbá három szakfordító és négy fordító- és tolmácsképzős hallgató fordítása alkotja. A kísérlet részeként először három hallgató nézte át az angol dokumentumot, akiket megkértünk gondolataik lejegyzésére, illetve arra, hogy legjobb tudásuk szerint fordítsák le a szöveget. A vizsgálati pontokat két oldalról közelítjük meg. Egyrészt a szöveg felől, nyelvhelyességi- és koherencia-szempontból, másrészt pedig az egyes terminusok fordításának oldaláról.

\subsubsection{A forrásnyelvi szöveg}

A forrásnyelvi „Affidavit” angol nyelven íródott, 191 szövegszóból áll. Az eredeti példány A3 méretü, fejlécén pakisztáni bankjegy szerepel, nyomtatott betủvel írt szövegtörzse hat bekezdés hosszú. A dokumentum alján az érintettek aláírása látható, a lapon nyolc bélyegző lenyomata szerepel, amelyek közül kettő olvashatatlan. A Pakisztáni Iszlám Köztársaság Nagykövetsége által rendelkezésre bocsátott dokumentumok fotójának közzétételére a személyes adatok eltávolításával sem érkezett engedély, így e leírás igyekszik szemléltetni a vizsgált okiratot. A vizsgált egységek az azonosításra alkalmas részletek behelyettesítésével, alattuk a vizsgálati pontok betűs megjelölésével, változatlan formában és sorrendben a következők:

(1) We (1) (név) S/O, (név) CNIC NO. (szám) \& (2) (név) W/O (név) CNIC NO. (szám) resident of (házszám) PRIMARY SCHOOL NO. (sorszám), SECTOR (sorszám) (város, ország) do hereby solemnly affirm and declare as under:

(a) S/O, CNIC NO., W/O, PRIMARY SCHOOL NO, hereby solemnly affirm and declare as under 
(2) That the deponents are fully conversant with the contents of this affidavit.

(b) deponents, fully conversant, affidavit

(3) That the deponents is real Parent of Mr. (név) S/O (név, születési idő) having CNIC NO. (szám), Passport No. (szám).

(c) deponents, real Parent, Mr. (név),

(4) That our said son at present is residing in Hungry (sic!), he is still bachelor / single neither engaged with any girl in Pakistan.

(d) Hungry, bachelor/single neither engaged, any girl

(5) That he is mature, independent and he has full right to get married with any girl with his own choice. We have no objection and allowed him to do so.

(e) mature, independent, has full right to get married with, any girl, with his own choice, no objection, allowed him

(6) Verified that the contents of this affidavit are true and correct to the best of our knowledge and belief nothing has been mis-stated or concealed wherein.

(f) verified, true and correct, to the best of our knowledge and belief, nothing has been mis-stated, concealed

További vizsgálati pontok találhatóak a hivatali bélyegzők szövegében, amelyek az azonosításra alkalmas részletek kihagyásával a következők:

(7) Attestation stamp

(8) Attested

(9) Magistrat $1^{\text {st }}$ Class

(10) Assistant Director (Consular-1)

(11) Advocate High Court

(12) Notarised to take Effect in all countries in \& out of Pakistan, Under International Law

(13) Ministry of Foreign Affairs

A jelölt vizsgálati pontok a hivatali dokumentáció terminusait és a fogalmazás különleges módját foglalják magukba. A hivatali terminológia kérdését több szempontból is érdekes megvizsgálni. Egyrészt, mivel a pakisztáni intézmények nevei és az egyes beosztások problémát okozhatnak a magyar rendszerrel való 
párhuzamba állítás során, mivel a két ország közigazgatási rendszere eltérö. A közigazgatási rendszer terminusainak megtalálásában a magyar fordító segítségére lehet a Pakisztáni Külügyminisztérium weboldala, ahol az egyes ügyintézési menüpontok alatt bővebb kontextus segíti a tájékozódást, leolvasható, hogy mely ügyintézést mely részleg végzi, milyen dokumentumokat kell benyújtani a kívánt adminisztrációs folyamat teljesítéséhez, illetve a keresett dokumentumtípus definíciója is szerepel.

A Pakisztáni Külügyminisztérium az „Affidavit” dokumentumtípust a következőként definiálja:

Only three types of affidavits are attested by the Ministry i.e. family reunion (children visas), financial support, un-married status (by parents, incase parents are deceased then by close blood relatives). The above-mentioned affidavits are required to be made on stamp papers. Attestation of a magistrate is compulsory and the signatory is required to come in person.

A Külügyminisztérium kizárólag háromféle nyilatkozatot hitelesít: családegyesítési kérelmet (gyermek-vízum), anyagi támogatásról és egyedülálló családi állapotról szóló okiratot (amelyben a szülők, elhunyt szülők esetén a legközelebbi vérrokonok nyilatkoznak). A dokumentum kizárólag illetékbélyeggel ellátott íven nyújtható be. Tartalmaznia kell bírói felülhitelesítést, feltétel a nyilatkozattevő személyes jelenléte.

(Forrás: http://www.mofa.gov.pk/content.php\#AFFI, Elérés: 2019. 11. 25., a szerző fordítása.)

A vizsgált dokumentum a Pakisztánban élő szülők beleegyezése fiuk magyarországi házasságkötésébe, amelyet a Pakisztáni Nagykövetségen kell benyújtani az úgynevezett házassági igazolás kiállításához, amelyre pedig a magyar hatóságok anyakönyvezéséhez van szükség. A szülők nyilatkoznak arról is, hogy gyermeküknek jogosultak engedélyt adni a házasságkötésre, mivel ők a nagykorú gyermek vér szerinti szülei (szülők hiányában a legközelebbi vérrokonságban állók adhatnak engedélyt). Nyilatkoznak gyermekük egyedülálló, elvált, vagy özvegy családi állapotáról is, amely alapján nincs akadálya a házasság megkötésének. Illetve, hogy a házastársválasztás jogát átengedik nagykorú gyermeküknek.

A magyar fordító bizonytalan lehet a dokumentum több pontjával kapcsolatban, valószínüleg ismeretlen az eskü alatt tett nyilatkozat fogalma, idegenszerü lehet továbbá a szülők hivatalos engedélyének kikérése a nagykorú gyermek házasságkötésével kapcsolatban.

Továbbá az iratok nem mindig egyszerüen értelmezhetőek. Mayoral a szokványos angol nyelvhasználathoz képest számos eltérést talál a pakisztáni nyelvhasználatban, amelyekről nem lehet megállapítani, hogy a pakisztáni angol jellegzetességeit mutatják, vagy a dokumentumot megalkotó ügyintéző nyelvi hiányosságait jelzik. Általában mindkét eset fennáll, a fordító munkáját ráadásul számos gépelési hiba is nehezíti, mivel sokszor még egyazon dokumentumon belül is előfordul egyazon szó háromféle írásmóddal. A jelenség oka lehet, hogy a dokumentum kiállítói valószínúleg nem jártasok a latin betưk használatában 
(Mayoral 2003:19), mivel az urdu írásmódja az arabhoz és perzsához áll közel, továbbá „jobbról balra” olvassák. A következőkben megvizsgáljuk a kulturális távolságból eredő fordítási kihívásokra született megoldásokat.

\subsubsection{A forrásnyelvi szöveg hiteles forditása és hivatalos forditása}

Magyarországon a hiteles fordítással kapcsolatos feladatokat az irányadó jogi szabályozás alapján az Országos Fordító és Fordításhitelesítő Iroda zártkörűen működő részvénytársaság (a továbbiakban: OFFI) látja el (Boóc et al. 2006: 126). Az okiratfordításokra általában valamilyen bírósági vagy hatósági eljárásban van szükség, ugyanis a jogalkalmazó szervek gyakran kötik a fordítások felhasználását olyan megerősítéshez, amellyel ezeknek a fordításoknak a rangja - bizonyító erejüket tekintve - a közönséges fordítások fölé emelkedik (Belcsák 2019: 113). A hiteles fordítás az annak készítésére jogosult által okiratnak minősülő forrásnyelvi iratról, az okirat tartalmának és alaki kellékeinek, továbbá a jogosult okiratfordításra vonatkozó belső szabályzatainak figyelembevételével készített ellenőrzött (lektorált) fordítás, amely hủen adja vissza a forrásnyelvi okirat tartalmát, így hatósági eljárásban való felhasználásra a forrásnyelvi irattal azonos súllyal alkalmas (Galli 2011).

A 3.1.1. pontban megjelölt terminusok és szókapcsolatok hiteles magyar fordításait a következőkben adjuk meg:

(a) fia, számítógépes országos személyazonosító igazolványának száma, felesége, Primary School No., ezennel ünnepélyesen kijelentjük és megerősítjük az alábbiakat:

(b) eskü alatti írásos nyilatkozatot tevő személyek, teljes mértékben tisztában vannak, eskü alatt tett írásos nyilatkozat

(c) eskü alatti írásos nyilatkozatot tevő személyek, ténylegesen a szülei, (név) úrnak, fia

(d) Magyarország, még nőtlen, nem házas, és nincs eljegyezve sem, egyetlen lánnyal sem

(e) nagykorú, önálló, teljes mértékben jogosult házasságot kötni, saját választása szerint, nincs ellene kifogásunk, megengedtük neki

(f) megerősíttetik, megfelelnek a valóságnak és pontosak, legjobb tudomásunk és hitünk szerint, semmi nem lett tévesen kijelentve, elhallgatva.

A dokumentumban továbbá megfigyelhető, hogy a latin betűvel írt tulajdonnevek átírásakor a fordítás változtatás nélkül követi az írásmódot. Ez esetben egyértelmű volt a nevek átírásának mikéntje, mivel a forrásszövegben csak a magyar ábécé karakterkészletében szereplő betűk találhatóak meg.

A forrásnyelvi dokumentumon szereplő bélyegzők szövegének hiteles magyar fordításai a következők:

(1) Attestation stamp: Hitelesítő bélyeg;

(2) Attested: P.H.: HITELESÍTVE;

(3) Magistrat $1^{\text {st }}$ Class: P.H.: 1. osztályú bírói jogú tisztviselő; 
(4) Assistant Director (Consular-2): igazgatóhelyettes (konz-II.);

(5) Advocate High Court: Ügyvéd, Felsőbíróság;

(6) Notarised to take Effect in all countries in \& out of Pakistan, Under International Law: Közjegyzőileg hitelesítve - hatályba lép valamennyi országban, Pakisztánban és azon kívül is, a nemzetközi jog értelmében;

(7) Ministry of Foreign Affairs: Külügyminisztérium.

Látható, hogy az OFFI tárgyilagos, hivatalos stílusban, pontos fordításokat alkalmazott. A nehezen értelmezhető real parents kifejezést a ténylegesen a szülei szókapcsolat fedi, amelynek ez esetben megkérdőjelezhető a helyénvalósága, mivel a „ténylegesen” többféleképpen értelmezhető; jelenthet vérrokonságot, de nem zárja ki a jogi értelemben vett szülőséget sem, amely például örökbefogadással, kiskorú és fiatalkorú esetén gyámsággal és akár ideiglenes elhelyezéssel is létrejöhet. Felmerül a kérdés, hogy esetleg azért nem „vér szerint szülőkként" szerepelnek a magyar fordításban, mivel ez a fordító számára nem volt biztosan megállapítható a forrásnyelvi kifejezésből. A Pakisztáni Külügyminisztérium honlapján a dokumentum leírásából a fordító következtethetett volna a vérrokonságra.

A dokumentum többes szám első személyben fogalmaz, a nyilatkozattevők szemszögéből. A magyar hivatalos dokumentációról az olvasónak általában a személytelen fogalmazás és a merev jogi szaknyelv juthat eszébe, azonban a vizsgált dokumentumra ez nem jellemző. A lakcímben szereplő ,általános iskola" címrészlet használata érdekes, amely itt a fordításban is angolul szerepel. Bár a szakfordítók körében elfogadott, hogy nem fordítanak címeket, hiszen akár levélben keresik meg az érintettet, akár a személyes dokumentumait ellenőrzi valamely hatóság, - feltételezve, hogy az angol forrásnyelvi dokumentum eredeti formában használta a személyes adatokat - csak így biztosítható, hogy megkeresés célba ér, a későbbiekben tárgyalt kísérletben mégis akadt olyan fordító, aki lefordította, mivel az általános iskolát valószínúleg nem tartotta a lakcím részének. Az ok valójában prózai, a lakosok a lakóhelyükhöz legközelebb eső állami intézmény címe alatt is regisztrálják lakcímüket, amely ez esetben éppen egy általános iskola. A kulturális háttérismeret tehát fontos szempont a helyes fordításhoz, és hiánya még a szakmai normákban jártas fordítót is elbizonytalaníthatja. Hasonló esetben érdemes a kérdéses részletet a megrendelővel egyeztetni.

A forrásszöveg másik fordítását egy iszlámábádi fordítóiroda készítette, valószínüleg gépi fordítóprogrammal, lektorálást nélkülözve. A szerző feltételezi továbbá, hogy magyarul tudó fordító sem volt az iroda portfóliójában, mivel a fordításban számos helyen felcserélve használták a szavak elsődleges és másod- illetve harmadlagos jelentéseit. A fordítás érdekessége, hogy a Pakisztáni Külügyminisztérium bélyegzője miatt annak ellenére is hivatalos fordításnak minősül, hogy a következőkben a szemléltetés kedvéért bemutatott megoldásokat alkalmazza, amelyek egyébként nyelvészeti szempontú elemzésre alkalmatlanok. Azonban, ha a Nagykövetség diplomáciai felülhitelesítéssel látja el a Pakisztáni Külügyminisztérium bélyegzőjét, úgy az ehhez hasonló fordítás is eljuthat a magyar hatóságokhoz. 
(a) fia, Nemzeti személyi igazolvány száma, Felesége, Általános iskola száma, Tegyenek ünnepélyesen megerősítik és kijelentik,

(b) hivatalnokok, teljes mértékben ismerik, bizonylatot

(c) hajtóanyagok/álszenvedő, MR tényleges szülők, s / o

(d) a mai fiunk éhesen él, még mindig apja vagy egyedül, senki nem vesz részt Pakisztánban

(e) érett, független, teljes joggal férhessen házassághoz bármelyik lányhoz, saját választása szerint, nincs kifogásunk, és megengedte neki, hogy ezt tegye

(f) ellenőrizte, tartalma igaz és helyes, a legjobb tudásunk és meggyőződésünk szerint, semmit nem mondtak el vagy rejtettek.

E fordítás a szöveg formaiságát, elrendezését tekintve sem tükrözi az eredetit, szkoposza szempontjából valószínűsíthető, hogy funkcióját sem tudja betölteni. Kivéve, ha a hitelesített fordítás puszta megléte betölti a szkoposzt, azonban ez nem bizonyított.

\subsubsection{A forditott korpusz}

A fordítási kísérletben három szakfordító és négy fordító- és tolmácsképzőt végző hallgató vett részt, egyikük sem rendelkezett számottevő ismerettel sem Pakisztán, sem a hasonló témájú hivatalos dokumentumok fordítása terén. A kísérlet megkezdése előtt három hallgató áttekintette a szöveget, és problémás pontként jelölte meg a dokumentum címét, a betüszavakat, a címben szereplő általános iskolát, a megfogalmazás módját, a bélyegzőkön szereplő intézmények neveit és tisztviselők beosztását, illetve a teljes dokumentum kiállításának célját is különbözőképp értelmezték.

A kísérlet a részvevők egyidejű jelenlétével, két csoportban zajlott, külön számítógépeken. A fordítók bármilyen internetes és nyomtatott forrást használhattak, azonban nem egyeztethettek a kérdéses pontokról. Az instrukciók között szerepelt a dokumentum formai reprodukciója, az összes olvasható elem maradéktalan lefordítása az olvashatatlan részek megjelölésével, továbbá az is, hogy külön dokumentumban, vagy a fordításban széljegyzetként jegyezzék le felmerülő fordítási problémáikat, gondolataikat, és hogy melyik forrásban találtak rá a helyesnek vélt megoldásra.

A fordítást átlagosan másfél óra alatt végezték el, hosszabb idő alatt, mint amennyire számítottak. A fordítók anonimitását megőrizve, véleményüket és megoldásaikat F1, F2, F3, F4, F5, F6 és F7 kódok jelölik.

A kutatás a 3.1.1. pontban meghatározott harminckét terminus/egység elemzésére korlátozódik. A címet két kivétellel minden fordító Eskü alatt tett nyilatkozatként fordította, F6 fordító azonban Eskü alatt tett lemondó nyilatkozatot használt, F7 fordító pedig Házasságkötési tanúsitványt. Érdekes, hogy F6 fordító megjegyzése szerint megpróbált a szülők által kényszerített házasságról való lemondásról szóló nyilatkozat hivatalos neve után kutatni, azonban nem sikerült megtalálnia. Ilyen dokumentum valójában nem ismeretes, azonban a fordító valószínúleg elbizonytalanodott az ismeretlen dokumentumtípus lát- 
tán, ezért nem volt biztos abban, hogy esetleg rossz módon kereste azt. F7 fordító pedig a szótári jelentések alapján Budaörs város honlapján megtalálta a külföldiek házasságkötéséhez szükséges dokumentumok listáját, és az alapján azonosítva az okiratot konkretizálta a címet. Ô azonban az ügyintézésben egy lépcsőfokkal későbbi okirat nevét találta meg, ez az Eskü alatt tett nyilatkozat ugyanis feltétele a házasságkötési tanúsítvány kiállításának, de nem ugyanaz a dokumentum.

$\mathrm{Az}$ S/O (son of) rövidítés tekintetében az különböző nézőpontból használt apa és fia megoldások dominálnak, azonban F6 fordító naszab megoldása kitünik a sorból. A fordítói jegyzetből kiderül, hogy egy arab szakos tanulmányban találta meg kifejezést, ahol a leszármazás leírására használták. A szerző a számára is ismeretlen terminus helyességéről kikérte egy pakisztáni személy véleményét, ez alapján e fordítás hibás, mivel a „shajra e nasab” kifejezés a teljes családfát, leszármazást jelenti, továbbá a naszab önmagában nem értelmezhető a pakisztáni nyelvhasználatban. F6 fordító a W/O (wife of) rövidítés fordítására is a naszabot adta meg, amely itt sem állja meg a helyét.

A címben szereplő általános iskola változatos fordítási megoldásokat adott a kísérlethez. F1 és F2 fordító általános iskolának fordította, F6 elemi iskolá$n a k$, a többi fordító pedig meghagyta a forrásnyelvi változatot. Felmerül annak a valószínüsége, hogy a fordítók számára nem volt egyértelmü, hogy az utca és házszám szerepeltetése mellett milyen jelentősége van az általános iskolának, F6 fordító térképen is igyekezett megtalálni, ezért nem a szakmai kompetencia hiánya okozhatta a cím lefordítását, hanem a kulturális háttérismeret hiánya.

Terminológiai konzisztencia a Deponents fordításában egyik fordító munkájában sem figyelhető meg. Az OFFI fordításában a dokumentum neve alapján eskü alatti írásos nyilatkozatot tevö személyek a helyes megoldás, a kísérletet elvégző fordítók nyilatkozattevők, felesketett tanúk és tanúk megoldásokat is alkalmaztak, F1 fordító pedig átfogalmazta a mondatot, így kihagyta a kifejezést. F6 fordító különösnek találta, hogy a „szerződést kötő felek” és a tanúk megegyeznek, mégis e megoldás mellett döntött. Talán segített volna a fordítóknak, ha a szöveget távolabbról vizsgálják és az ugyanazokra a személyekre vonatkozó elnevezéseket egységesítik.

A real parent of hasonlóan problémás kifejezés, vér szerinti és valódi szülők szerepelnek a fordítási megoldásokban. F6 fordító megjegyzése szerint gondot okozott a megoldás, mivel a forrásszövegben szereplő deponents is real Parent of kifejezés hanyagság vagy az angol nyelv nem megfelelö ismerete miatt hibás.

A Hungry (sic!) elgépelését F2 fordító mulatságosnak tartotta és a megbízóval egyeztetné, hogy biztosan Magyarországról van-e szó, F6 fordító pedig csalódottságát fejezte ki miatta. Az elgépelés visszavezethető akár Magyarország ismeretlenségére Pakisztánban, a közel azonos hangalakra, vagy a korábbiakban tárgyalt Mayoral 2014 gondolatmenetre, amely feltételezi, hogy a dokumentumot kiállító személyek nem jártasok a latin betúk használatában, ezért egy szó többféle írásmóddal is szerepelhet (akár egy dokumentumon belül is).

A családi állapotra vonatkozó he is still bachelor/single neither engaged with any girl in Pakistan állításnál $\mathrm{F} 3$ fordító felvetette a kétértelmüséget. Szerinte a pakisztáni házas- és jegyestársra és a Pakisztánban meglévő (de nem feltétle- 
nül pakisztáni állampolgárral kötött) házassági vagy jegyességi viszonyra is vonatkozhat. F6 fordító felvetette, hogy az okirat szövegének megfogalmazói nem ismerik eléggé az angol nyelvet egy hivatalos dokumentum megírásához. A girl háromszor lány, kétszer nő, egyszer hajadon megoldásokban mutatkozott, F4 fordító azonban kihagyta és átfogalmazással megnősülni főnévi igenévre cserélte. A forrásnyelvi szövegben a szokatlanul informális kifejezést a legtöbb fordító megtartotta.

A dokumentum következő bekezdésében a szülők engedélyt adnak a házasságkötéshez, a We have no objection and allowed him to do so. mondattal. F6 fordítóban kétségek merültek fel a dokumentum céljával kapcsolatban, a kifejezésmód különössége és a kijelentés abszurdnak tűnt számára, felmerült benne, hogy talán humorosnak szánt dokumentumról van, azonban a hivatalos formára tekintettel mégis megtartotta a hivatalos stílust. Fordítása egyedi, a házasságot a frigy szinonimával jelölte: a frigyhez engedélyünkkel hozzájárulunk.

A bélyegzők tekintetében a fordítások nagyon változatosak. A bélyegzők alakját és elhelyezkedését egy fordító sem reprodukálta, ezért a bélyegző szóval és a köznyelvi pecsét szinonimával jelezték, hogy nem a szövegtörzshöz tartozó elem fordítása következik. A bélyegzők kör, ellipszis és háromszög alakúak, megkülönböztetésül $\mathrm{F} 1$ fordító sorszámmal jelölte, F3 fordító a bélyegző alakjával fejezte ki (körbélyegző, háromszögbélyegó) F2 fordító pedig a bélyegző elhelyezkedését is hozzáadta a fordításhoz (pecsét bal oldalt, pecsét a bal oldali pecséten). F4 fordító reprodukálta a bélyegzők elhelyezkedését az oldalon, F5 fordító pedig a fordítás végén egy csoportban adta meg az összes bélyegző fordítását. A forma újraalkotása szempontjából nem helyes ez a megoldás, és előfordulhat, hogy a dokumentum hitelességének is része a bélyegzők helyzete a papíron. Anélkül, hogy a fordító erről megbizonyosodott volna, nem volt célszerű ezt a megoldást választania.

A fordításban kétségkívül a hivatalok nevei és tisztviselők beosztásának fordítása okozták a legtöbb dilemmát. Mivel a pakisztáni közigazgatási és igazságszolgáltatási rendszer a magyartól különbözik, illetve működésének megértése és a jogkörök gyakorlásának tisztázása a fordítótól bővebb utánajárást igényel, a helyszínen fordítás és a megrendelő véleményének kimaradása tovább nehezítette a fordítási kérdés megválaszolását.

$\mathrm{Az}$ Advocate High Court az F1 fordító munkájában Legfelsőbb Bíróságként, F2-nél Legfelsőbb Ügyészségként, F3-nál felsőbirósági ügyvédként, F4-nél Főtörvényszéki ügyvédként, F5-nél és F6-nál $A$ legfelsőbb biróság ügyvédjeként, szerepel, F7 fordító pedig kihagyta a fordításból. Sokszínủ megoldások születtek a Magistrat $1^{\text {st }}$ Class intézménynévre is. F1 fordító olvashatatlannak találta a bélyegzőt, F2 elsö fokú igazságügyi tisztviselóként jelölte, F3 úgyszintén olvashatatlannak találta, F4 elsőfokú biróságként fordította, F5 újból nem tartotta olvashatónak, F6 és F7 fordító pedig kihagyta a fordításból. F3 fordító a teljes dokumentumból a bélyegzők fordítását tartotta a legnehezebb feladatnak. A Notarised to take Effect in all countries in $\mathcal{E}$ out of Pakistan Under International Law bélyegző a várttal ellentétben egy fordítónak sem okozott gondot, és jegyzetben sem jelölték, hogy a countries in $\mathcal{E}$ out of Pakistan értelmezése fennakadással járt volna. 
A bélyegzők fordításakor két szempont is felmerülhet a fordítóban. Egyrészt, mivel a bélyegzők célja a dokumentum hitelességének bizonyítása, így visszaellenőrizhetőségének biztosítása, dilemmát okozhat, hogy egyáltalán le kell-e fordítani. E szempontból kézenfekvő lehet úgy vélekedni, hogy egy bélyegzőt sem kell a fordítónak lefordítani, mivel csak a célnyelvi dokumentum birtokában a fordítási megoldások sokszínűségére alapozva nehéz feladat lenne feltérképezni, hogy vajon melyik intézmény lehetett a kiállító hatóság, fóleg egy távoli és nagyon eltérő kultúrájú ország esetén. A bélyegzők fordításának mégis akkor lehet jelentősége, ha a felhasználó vagy a rendeltetési ország hivatala szempontjából jelentősége van, hogy az okirat milyen jellegü hitelesítésen ment keresztül, ez pedig jó eséllyel kiderülhet a bélyegző szövege alapján.

A fordítói kommentárok alapján valószínűsíthető, hogy fordítók előzetes háttértudás hiányában saját földrajzi ismereteik és a hazai közigazgatási rendszerben szerzett tapasztalatuk alapján alkottak véleményt a forrásnyelvi dokumentumról. Szakirányú tapasztalatuk segített a célirányos internetes keresésben, azonban a megerősített források és a párhuzamos szövegek hiánya megnehezítette munkájukat. A dokumentum szkoposzát az összes fordító szem előtt tartotta, így még a forrásdokumentum komolyságát kétségbe vonó F6-os számú fordító is nagy figyelmet fordított a végeredmény hivatalos stílusára. A fordítók munkáját nagy mértékben segítette volna, ha rendelkeznek releváns háttérismeretekkel, fel tudják venni a kapcsolatot a terület szakértőjével, vagy párhuzamos szöveg alapján könnyebb döntést tudnak hozni egy-egy terminus helyességével vagy fogalmazási mód megfelelőségével kapcsolatban.

Kulturális háttérismeretek hiányában születtek hibás megoldások, amelyek nem tudhatók be sem a fordítói szakértelem hiányának - hiszen a könnyen azonosítható elemek esetén megfelelő megoldásokat alkottak - sem a nyelvismeret hiányosságainak, mivel a fordítók megtalálták a célnyelvi megfelelőket, de nem mindig helyesen választották ki a kontextusba illő vagy terminológiailag helyes ekvivalenst. Ez pedig a kulturális háttérismeret hiányával magyarázható.

\section{4. Összegzés}

A Pakisztáni Iszlám Köztársaság területén kiállított dokumentumok magyar fordítása a térségből hazánkba érkező személyek dokumentációja szempontjából fontos témakör. A hivatalos személyi dokumentumokban szereplő kulturálisan kötött kifejezések, reálialexémák a magyar fordító számára idegen hatást kelthetnek, a benne szereplő tulajdonnevek, intézménynevek, fogalmazási módok különös kihívás elé állítják a nyelvi szakembert.

A szerző előző tanulmánya Benedek (2019) folytatásaként egy Affidavit dokumentum fordítási kísérletét végezte el három szakfordítóval és négy fordító- és tolmácsszakos hallgatóval. A fordítások értékelésének kiindulópontja az OFFI által készített hiteles fordítás, a forrásnyelvi szöveget ezen kívül öszszevetette egy pakisztáni fordítóiroda által kiadott, valószínűleg géppel készített fordítással is, amelynek érdekessége, hogy számos hibával együtt is eljuthat a magyarországi végfelhasználóhoz. Az esettanulmány egy várhatóan nagyobb 
mintán végzett kutatáshoz készült előtanulmány, amely a következő kutatási hipotézist állítja fel: a fordítónak nemcsak szaktudással, de kulturális háttérismeretekkel is rendelkeznie kell a megfelelő fordítás megalkotásához. A megértést segíti, ha a fordító előzetes ismereteket szerez a kiállító ország közigazgatásáról, dokumentumtípusairól, és feltérképezi, hogy milyen eseményt, folyamatot ír le a dokumentum, továbbá milyen jelentősége van a kibocsátó kultúrában.

Az idegen kultúrából származó dokumentum fordítására vállalkozó magyar szakember hasznát veheti a megrendelő kikérdezésének, mivel valószínüsíthető, hogy ő rendelkezik valamilyen ismerettel a szövegben szereplő jelenségekről. Érdemes a kiállító országok minisztériumainak, közigazgatási egységeinek honlapjait meglátogatni, itt tágabb képet kaphatunk a kontextusról és a dokumentum szkoposzáról. Nem lehetetlen vállalkozás telefonon vagy elektronikus levélben felkeresni a kiállító ország magyarországi külképviseletét, hiszen általában magyar asszisztensek segítik az ügyintézést, akik esetleg jártasok a keresett terminus fordításában. Hasznos lehet internetes szakmai fórumokon érdeklődni, vagy megkeresni az adott kultúrkörből származó, Magyarországon tartózkodó közösség weboldalát. A fordító a messzi kultúrában keletkezett szövegek esetén nehéz, de korántsem lehetetlen feladatra vállalkozik.

\section{Irodalom}

Banczerowski J. 2008. A világ nyelvi képe. A világkép mint a valóság metaképe a nyelvben és a nyelvhasználatban. (Segédkönyvek a nyelvészet tanulmányozásához; 86.) Budapest: Tinta Könyvkiadó.

Benedek E. 2019. Kulturális átváltások pakisztáni hivatalos személyi dokumentumok magyar fordításában. Forditástudomány 21. évf. 1. szám. 43-61.

Belcsák R. F. 2019. A hitelesítés mint jogilag megalapozott tevékenység. In: Szoták Sz. (szerk.) Az állami forditószolgálat 150 éve. Budapest: OFFI Zrt. 87-126.

Boóc Á., Dömötör L., Sándor I., Szappanos G. 2006. A hiteles forditás és a hiteles tolmácsolás alapvető kérdései. Budapest: HVG-ORAC Lap- és Könyvkiadó Kft.

Catford, J. C. 1965. A Linguistic Theory of Translation. An Essay in Applied Linguistics. London: Oxford University Press.

Galli P. 2011. A hiteles fordítás helye a közigazgatásban. In: Dróth Júlia (szerk.) Szaknyelv és szakforditás. Gödöllő: Szent István Egyetem. 59-75.

Heltai P. 2012. Kultúraspecifikus kifejezések és reáliák. Forditástudomány 15. évf. 1. szám. 32-53.

Hofstede, G. 1994. Cultures and Organisations, Software of the Mind. Paperback edition. London: HarperCollins Publishers.

Klaudy K. 1999. Bevezetés a forditás elméletébe. Budapest: Scholastica.

Klaudy K. 2013. Nyelvi és kulturális aszimmetria a reáliák fordításában. In: Bárdosi V. (szerk.) Reáliák - a lexikológiától a frazeológiáig. Értelmezések és forditási kérdések. Budapest: Tinta Könyvkiadó. 86-91.

Mayoral, R. 2014. Translating official documents. (Translation practices explained). New York: Routledge.

Mujzer-Varga K. 2007. A reáliafogalom változásai és változatai. Fordítástudomány 9. évf. 2. szám. 55-84. 
Mujzer-Varga K. 2009. Honosítás és idegenítés Örkény István Egyperces novelláinak fordításaiban. In: Zimányi Á. (szerk.) A tudomány nyelve - a nyelv tudománya. Alkalmazott nyelvészeti kutatások a magyar nyelv évében. XIX. Magyar Alkalmazott Nyelvészeti Kongresszus. Eger, 2009. április 16-18. 500-507.

Nida, E. A.1964. Toward a Science of Translating. Leiden: Brill.

Nida, E. A., Taber, Ch. R. 1969. The Theory and Practice of Translation. Leiden: Brill.

Tellinger D. 2005. Etnokulturémák szerepe a müfordításban. Publicationes Universitatis Miskolcinensis. Sectio Philosophica 10. évf. 3. szám. 123-129.

Vermeer, H. J. 1978. Ein Rahmen für eine allgemeine Translationstheorie. Lebende Sprachen. Vol. 23. No. 3. 99-102.

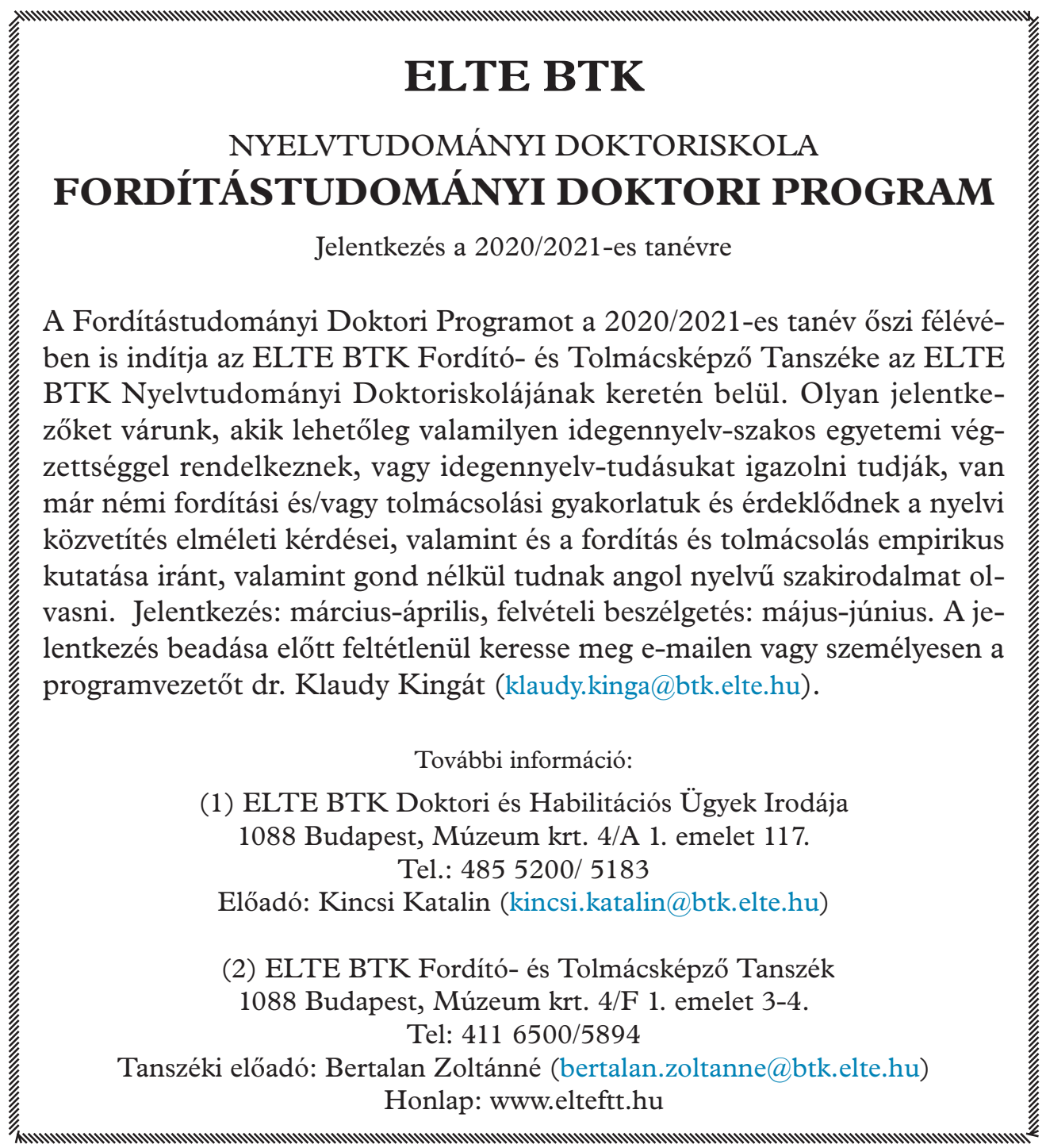

